\title{
The Brissot Dossier
}

\section{Citation}

Darnton, Robert. 1991. The Brissot dossier. French Historical Studies 17(1): 191-205.

\section{Published Version}

http://dx.doi.org/10.2307/286284

\section{Permanent link}

http://nrs.harvard.edu/urn-3:HUL.InstRepos:3403050

\section{Terms of Use}

This article was downloaded from Harvard University's DASH repository, and is made available under the terms and conditions applicable to Other Posted Material, as set forth at http:// nrs.harvard.edu/urn-3:HUL.InstRepos:dash.current.terms-of-use\#LAA

\section{Share Your Story}

The Harvard community has made this article openly available.

Please share how this access benefits you. Submit a story.

\section{Accessibility}




\title{
The Brissot Dossier
}

\author{
Robert Darnton
}

Although I welcome Frederick de Luna's rereading of Brissot's life and works, I cannot agree with his characterization of my own work as "sustained denigration." My purpose was not to declare Brissot guilty of spying for the police but rather to understand him and the milieu in which he wrote. Out of that attempt grew a general thesis about Grub Street as an ingredient in prerevolutionary France, which in turn fits into the larger effort to develop a social history of ideas. I would like to take de Luna's essay as an opportunity to discuss some of those larger issues. But first I had better return to the case of Brissot.

I started to study Brissot's career in 1960, while doing research on The Gallo-American Society, a Bachelor of Philosophy thesis at Oxford, which I completed two years later. At that time, I saw Brissot very much as de Luna sees him now. The future leader of the Girondins seemed to be a disinterested idealist, who threw himself into the defense of slaves, the poor, Quakers, Genevans, Jews, Romanians, and all sorts of worthy causes, including the American variety of republicanism, for which he died on the guillotine. I still think there is much to be said for that view, which coincides with the picture Brissot painted of himself in his memoirs.

But after first meeting Brissot in the company of people like Clarkson, Paine, and Jefferson, I began following his trail through archival material. I ran into him in many unexpected places: reports on libelous pamphleteering by British agents in London, letters about indigent writers by Parisian booksellers and Swiss publishers, accounts of stockjobbing on the Paris Bourse, and correspondence about speculation on the currency issued by the colonies during the American Revolution. What especially brought me up short was the reference to Brissot's spy-

Robert Darnton is Shelby Cullom Davis Professor of European History at Princeton University. His last two books are: Edition et sédition: L'Univers de la littérature clandestine au XVIIIe siècle (Paris, 1991) and Berlin Journal, 1989-1990 (New York, 1991). 
ing in the papers of Jean-Charles-Pierre Lenoir, the former lieutenantgeneral of police in Paris. Could the supreme idealist of the French Revolution have been a paid informant of the police during the mid-1780s?

I was not so naive as to take Lenoir's statement at face value, and I certainly felt no sympathy for the police as opposed to one of their most illustrious victims. But a disparity existed between the Brissot of the memoirs and the Brissot who appeared in all the manuscript sources. That disparity opened up a fissure in the Enlightenment-to-Revolution view of the eighteenth century that I had assimilated as an undergraduate in the 1950s, when high intellectual history was at its height. Would it be possible to strike out in a new direction, something that I liked to call "low intellectual history" but that promised to fare better under a less provocative name: the social history of ideas?

Social history was just beginning to undergo revival at that time; the pure history of ideas had become increasingly removed from the experience of ordinary human beings; and it seemed possible to look at the late Enlightenment as Edward Thompson, Eric Hobsbawn, George Rudé, and Richard Cobb had examined the history of labor and popular protest, "from below." That phrase may sound archaic or overused today, and it may have been too programmatic in the $1960 \mathrm{~s}$, but it seemed to offer a way of getting out from under the great-men-greatbooks approach to intellectual life. Instead of merely studying philosophic texts, I wanted to see how the philosophes lived, day-to-day and terre à terre, within the social order of the Old Regime and to study how their ideas circulated within that society.

As a representative, would-be philosophe of the revolutionary generation, Brissot seemed to be an ideal case to study. He became a central figure in the doctoral dissertation I completed at Oxford in 1964, Trends in Radical Propaganda on the Eve of the French Revolution (unpublished but available from University Microfilm, Ann Arbor, Michigan). In fact, he became so central that I decided to write a biography of him and to produce an edition of his correspondence, which will eventually include nearly two hundred unpublished letters. Those two projects got shelved, however, while I worked on subjects that seemed more urgent, such as the history of books, intellectuals, and public opinion. But Brissot appears in many of those studies, and de Luna's essay provides an opportunity to go back over the question I raised twenty-two years ago: was Brissot a police spy? I believe he was. Can one convict him retrospectively of spying for the police? I think not. Let me explain. 
Historians may sometimes act like detectives, and they can hardly avoid making judgments, but I do not see why they should behave like judges in a court of law. ${ }^{1}$ I did not pretend to convict Brissot of espionage, but rather to weigh all the evidence, pro and con, and then to advance an interpretation of my own - that is, to make out a case, not to pass sentence.

Many of Brissot's contemporaries accused him of having been a police spy, but their arguments generally struck me as tendentious: Rivarol was trying to blacken the reputation of revolutionaries in general, Gouy d'Arsy to smear the opponents of the slave trade, François de Pange and Théodore Lameth to undercut the enemies of the reactionary right, Desmoulins to turn public opinion against the Girondins, Marat to wage a personal and political vendetta, François Chabot and Anarcharsis Cloots to damn Brissot in the Jacobin Club, J.-B.-A. Amar to condemn the Girondins before the Committee of General Security, and Robespierre to overwhelm them in the Convention. I have sifted through all these accusations and have found most of them unconvincing. Marat's remarks, for example, should be taken seriously because he was a close friend of Brissot's before the Revolution. But he makes Brissot out to have been a spy for Lenoir in 1787, when Lenoir had ceased to be lieutenant-general of police. And Pange errs in the opposite way: he claims the spying took place in 1780, before Brissot had any financial need to work for Lenoir. The charges and countercharges do not add up to anything conclusive; they merely show that Brissot was widely suspected of spying and that his enemies slung a great deal of mud at him.

I would never have expected to find a grain of truth in the mud had I not discovered the reference to Brissot's spying in the manuscript memoirs of Lenoir. But I never read Lenoir's papers uncritically. On the contrary, I stressed the importance of allowing for the obvious objection that, as a refugee from the Revolution, Lenoir had no love for revolutionaries. Because the documentation appears in my original article, I won't repeat it here. But because Lenoir's remark is so crucial to my argument, I will try to explain why I took it seriously. I propose to discuss: ( 1 ) the nature of the evidence in Lenoir's papers, (2) corroborating evidence, (3) counterevidence, and (4) circumstantial evidence.

${ }^{1}$ On the historian as detective, see Carlo Ginzburg, Clues, Myths, and the Historical Method, trans. John and Anne C. Tedeschi (Baltimore, 1989). Curiously, after turning up evidence in one archive indicating that Brissot spied for the police, I found evidence in another, which proved that Marat had not stolen some valuables from the Ashmolean Museum in Oxford, contrary to the assertion of some of his biographers. Robert Darnton, "Marat n'a pas été un voleur: Une Lettre inédite," Annales historiques de la Révolution française 185 (1966): 447-50. 
1. Lenoir's manuscripts. There is no reason to doubt the authenticity of Lenoir's papers in the Bibliothèque municipale of Orléans. Georges Lefebvre, who first went through them, pronounced them genuine, and I found that they conform to many other police records that I have consulted. But they are not simple and straightforward documents. Along with some finished essays, copied neatly in a scribal hand, they contain all sorts of notes and scraps, some of which are nearly illegible. Lenoir drew on the notes in writing drafts for a work which he intended to publish as his memoirs. But he never produced a draft of the chapter in which Brissot would have figured. So his remarks on Brissot and other writers are brief and elliptical.

In addition to the three sentences quoted from my article by de Luna, Lenoir referred to Brissot in a scribbled note, which I cited in a footnote: "The famous ["fameux"] comte de Mirabeau had been employed by the lieutenant of police, the famous Brissot de Warville also. The police employed them in producing and [circulating?] pamphlets." This note conforms closely to a fragment of the police archives published in 1838 by Jacques Peuchet: "The notorious ["fameux"] comte de Mirabeau and Brissot de Warville had been employed separately by the police in writing bulletins and other works and in spreading them throughout the public in order to contradict false stories and anecdotes."'2 To anyone who has followed Mirabeau's tortuous career as a pornographer and propagandist, sometimes for and sometimes against the Calonne ministry, the reference to Mirabeau is not surprising. Mirabeau received secret payments from the crown at the height of his influence during the Revolution. Nor is it surprising to find Brissot as a pamphleteer in Mirabeau's company, because Brissot contributed to several of the pamphlets that appeared under Mirabeau's name and that were used by their common benefactor, Etienne Clavière, to manipulate the stock market. But more on that later.

Is there anything inherently illogical or unbelievable about Lenoir's principal remark on Brissot's spying? Having read hundreds of police reports and interrogations in the Bastille, I have often come upon writers who offered to spy for the police in order to be released from confinement. I think Brissot may have done so, perhaps by approaching Goupil de Pallières, a police agent who had helped him escape embastillement in 1777 , but that is speculation on my part.

${ }^{2}$ Jacques Peuchet, Mémoires tirés des archives de la police (Paris, 1838), 3:17, quoted in my original article, "The Grub Street Style of Revolution: J.-P. Brissot, Police Spy," The Journal of Modern History, 40 (1968): 321. The article contains all the documentation and references in the original French, and so I have not repeated them here. 
Lenoir's papers merely contain the assertion that Brissot offered his services after his release from the Bastille, that Lenoir refused them, but that one of his secretaries engaged Brissot as a spy and that Lenoir received copies of Brissot's reports until shortly before retiring from the police in August 1785. Lenoir did not state that Brissot began spying as soon as he left the Bastille on 10 September 1784. So the fact that Brissot spent a few months at his mother-in-law's house in Boulogne in the autumn of 1784 and a few months in Châteaudun during the summer of 1785 does not invalidate Lenoir's statement.

Nor does the possibility that Brissot worked for one of Lenoir's secretaries rather than for Lenoir himself. The lieutenant general of police in Paris was an important official, the equivalent in some respects of a mayor and a minister of the interior, and he presided over a large bureaucracy. He did not normally deal with the hack writers and journeyman printers who were hired as spies by his subordinates. But he read many of the spies' reports, and he sometimes forwarded the reports to the Keeper of the Seals or the minister in charge of the Maison du Roi. In weighing Lenoir's remarks, one must consider the contemporary concept of "police" and also of "spy," which were very different from our own. Anyone curious to know how the Paris police actually functioned can consult some eighteenth-century treatises. ${ }^{3}$ Anyone who has consulted the documents will find that Lenoir's remarks on Brissot, and indeed everything in Lenoir's papers, conform to the usage of the Old Regime.

2. Corroborating evidence. Who was the secretary or subordinate of Lenoir's who allegedly hired Brissot? We don't know. My best guess is a certain Martin (I can't discover his first name), who is identified in the Almanach royal of 1784 as the secretary of police in charge of the Bastille and the illegal book trade. Brissot knew Martin as early as 1781, when he informed his publisher, the Société typographique de Neuchâtel, that its edition of Rousseau's works would have to compete against eight other editions, which soon would be smuggled into France, ac-

${ }^{3}$ See especially, Nicolas Delamare, Traité de la police (Paris, 1705-1738), 4 vols.; and Nicolas Toussaint Lemoyne Des Essarts, Dictionnaire universel de police (Paris, 1786-1790), 8 vols. For recent accounts of the Paris police, see Alan Williams, The Police of Paris, 1718-1789 (Baton Rouge, La., 1979) and Steven L. Kaplan, "Note sur les commissaires de police de Paris au XVIIIe siècle," Revue d'histoire moderne et contemporaine 28 (1981): 669-86. I have also discussed Lenoir's papers and published fragments of them in Robert Darnton, "Le Lieutenant de police J. C. P. Lenoir, la Guerre des Farines, et l'approvisionnement de Paris à la veille de la Révolution," Revue d'histoire moderne et contemporaine 16 (1969): 611-24; and Darnton, "The Memoirs of Lenoir, Lieutenant de Police of Paris, 1774-1785," The English Historical Review 85 (1970): $532-59$. 
cording to information that had reached Martin in the Paris police. A year later, Brissot wrote that "M. Martin, who seems to esteem me, to be attached to me, has assured me of his good will."' Two years later, soon after his release from the Bastille, Brissot wrote to Martin himself, thanking him "for the interest you have taken in my misfortune" and asking him to thank Lenoir for the sympathetic treatment Brissot had received in the Bastille.

From that point on, the correspondence of the STN demonstrates that Brissot remained on good terms with Martin, that he had inside information about the policing of the illegal book trade, and that the police had agreed, as a "favor," to let some of Brissot's own illegal books slip through their net. The most suggestive letter I found came from the STN's agent in Paris in February 1785:

M. de Warville [that is, Brissot de Warville] told me that at the last conversation he had with M. Martin, first secretary of the lieutenant general of police, he [Martin] said that no matter what route we should take to smuggle our books into Paris, he would find a way to discover it and to enforce his orders along the Swiss border. He would only permit M. de Warville to import 200 copies of volumes six through nine of the Bibliothèque philosophique into Paris. ${ }^{4}$

This material supports Lenoir's claim that Brissot worked for a secretary in charge of one of the departments of the police, but it is only corroborative, not conclusive evidence. I never argued that Brissot's connections with Martin before his embastillement prove that he must have spied for Martin afterward. My argument was more straightforward and less absurd: good relations with Martin in 1781-84 could have opened the way for Brissot to work for him in 1785 .

One cannot find corroborative evidence in the papers of the Bastille, because Brissot's dossier has disappeared from Ms. 12454 in the Bibliothèque de l'Arsenal, which concerns the affair for which he was arrested: the attempts of French expatriates in London to blackmail leading figures in Versailles by producing scurrilous pamphlets. There is no doubt that Brissot frequented this milieu in London and that he was an intimate friend of Anne-Gédéon Lafitte de Pelleport, the probable author of Le Diable dans un bénitier and Les Petits soupers et les nuits de l'hôtel de Bouillon. But there is no proof that Brissot collabo-

${ }^{4}$ J.-F. Bornand to the Société typographique de Neuchâtel, 19 Feb. 1785, quoted in "The Grub Street Style of Revolution," 325. Bornand was referring to Brissot's Bibliothèque philosophique du législateur, a ten-volume compilation, which the STN was marketing clandestinely in France. The police had seized a shipment of volume five, but Brissot persuaded them to release it. 
rated on these libelles, although he probably helped distribute them through his contacts in Boulogne. ${ }^{5}$

Why is Brissot's dossier missing? He offered his own explanation in his memoirs: his friend Pierre-Louis Manuel had given it to him so that "nothing concerning me should remain in the dung heap of the police." 6 Like Brissot, Manuel had lived down and out in Grub Street until the fall of the Bastille. Then he found a job in the new municipality created by the Revolution in Paris. In fact, he occupied the place in the police left vacant by the disappearance of Martin; and Brissot, who had emerged as the successful editor of Le Patriote français, hailed this turn of events as a stroke of poetic justice: "Our friend Manuel sets a very different style in the police department from that of his predecessor Martin, who used to distribute lettres de cachet and who tortured him, like me, in the depths of the Bastille." Instead of repressing illegal books, Manuel went through the papers of the Bastille, weeding and pruning, and published a sensational anthology of dossiers, La Bastille dévoilée. When he came to Brissot's dossier, he turned it over to Brissot and invited him to compose his own article. Brissot complied, not with the text of the documents but with an assertion of his selflessness: "The true cause of my detention was the zeal with which at all times and in all my writings I have defended the principles that are triumphing today."

3. Counterevidence. One can find many such proclamations of innocence in Brissot's writings. In 1790 he wrote the following account of his embastillement:

I was perishing in an underground cell, me, innocent . . . cut off from all mankind, from my wife, my child! They would not even let my letters reach my family, while swearing to me that the letters had got through. . . . The barbarians amused themselves at my tears and torments.

Manuscript records in a section of the Bastille archives that Manuel did not purge prove that Brissot was well supplied with food, laundry, and opportunities to take walks within the prison walls. His wife was per-

${ }^{5}$ See the documents published by Claude Perroud in J.-P. Brissot. Correspondance et papiers (Paris, 1912), 464-67. Perroud thought they might have been doctored, because they were published by Charles Théveneau de Morande during his polemics with Brissot, but Brissot never challenged their authenticity. I have collected a great deal of material on the London libellistes and plan to discuss it in detail in a later work.

6 This remark and the following are taken from "The Grub-Street Style of Revolution," 319-22, where the references to the original sources may be found. 
mitted to visit him, and so in his thank-you letter to Martin after his release from the Bastille, Brissot wrote:

Would you please convey my respects to $\mathrm{M}$. Lenoir along with all the feelings of gratitude that his generous and delicate treatment has inspired in me and in my wife? Please accept yourself her compliments and her thanks.

Like Manuel and many other hack writers, Brissot had powerful reasons to cover up his tracks in the police archives and to exploit the mythology of the Bastille by presenting himself as a victim of royal despotism. By the time he came to write his memoirs, he was fighting for his life. I find it neither surprising nor reprehensible that he pictured himself as an idealist and a revolutionary crusader before 1789 . Indeed, there was a great deal of truth in that view of his career, and Brissot may have convinced himself that it was entirely true-that is, that he had never collaborated in the slightest way with the London libellistes, the Grub Street hacks, the stock market manipulators, the American speculators, and the Paris police. Selective memory can work wonders, especially for a man attempting to justify himself before the Revolutionary Tribunal and the tribunal of posterity. I find Brissot's memoirs moving and revealing, but I do not think one should read them literally.

Nor do I claim that one should give an uncritical reading to the manuscripts Lenoir intended to publish as his memoirs. In my essay I stressed that Lenoir had plenty of reason to distort the past and to denigrate revolutionaries, because he wrote as an émigré at least fifteen years after the events he described. Are his memoirs less believable than Brissot's? Instead of pronouncing on the basis of the texts, I would recommend reading them with a great deal of skepticism and looking as hard as possible for evidence in other sources. De Luna has not found any new documentation. He merely disputes mine and accepts Brissot's writings at face value. The biographers of Brissot do not credit the story of his spying, it is true, but they did not know about the archival material that I turned up. In fact, it was only because I found so much new material, and so much that ran counter to Brissot's own account of his life, that I thought it worth writing another biography of him. ${ }^{7}$

7 The only biography published after the appearance of my article is Suzanne d'Huart, Brissot: La Gironde au pouvoir (Paris, 1986). It ignores the question of Brissot's spying, but it contains some new information, based on Brissot's interrogation in the Bastille, which suggests that he was implicated in the affairs of the London libellistes. The biography contains no footnotes or references, and I have not yet been able to consult the Brissot material recently deposited in the Archives nationales. 
There is only one biography of Lenoir. It credits his integrity and cites a good deal of contemporary evidence to confirm his reputation as an honest civil servant, but of course it may be as biased in his favor as Brissot's biographies are in favor of Brissot. ${ }^{8}$

4. Circumstantial evidence. De Luna devotes nearly two-thirds of his essay to a survey of Brissot's philosophic writings. I do not disagree with his account of this well-known material, but I find its implications puzzling. He seems to argue that because Brissot wrote highminded works he could not have spied for the police. For my part, I think Brissot's philosophical writing demonstrates a sincere desire to become a philosophe and that his embastillement brought about the final collapse of that ambition. It condemned him to a life in Grub Street, although he continued to search for a way out - first by emigration to America, then by throwing himself into the French Revolution.

If one limits the inquiry to Brissot's printed works, it is clear that the Bastille disaster divides his writing into two main varieties: before it, he devoted himself primarily to treatises like the Théorie des lois criminelles and $D e$ la vérité; afterwards, he wrote mainly pamphlets and journalism. That is not to say that Brissot did no pamphleteering before 1785 (I have identified two previously unknown early pamphlets of his that appeared anonymously), nor that he wrote nothing of a philosophic character after his release from the Bastille (his most important work, De la France et des Etats-Unis, was written with and subsidized by Clavière). It also does not vitiate Brissot's commitment to the antislavery movement and other noble causes. On the contrary, Brissot's campaigns for those causes seem all the more generous in that his own circumstances were so desperate. But his desperation forced him to live like a typical hack, making compromises and writing for money.

When the police released Brissot from the Bastille, he was ruined. He had lost the 4,000 to 5,000 livres that he had inherited from his father in the collapse of his London Lycée, and his partner in that enterprise, Desforges d'Hurecourt, was suing him for the 13,000 livres he had sunk into it. Meanwhile, Brissot's Swiss publisher, the Société typographique de Neuchâtel, was dunning him for a debt of 12,300 livres in printing expenses, and he had lost everything he owned, even the furniture in his London flat. To be sure, Brissot could delay paying Desforges while their dispute dragged on in court, and he could fob off the

${ }^{8}$ Maxime de Sars, Le Noir, lieutenant de police 1732-1807 (Paris, 1948). 
Swiss with proposals to compensate them in copies of his works. But how could he support his wife and children: Félix, born on 29 April 1784 and Edmé-Augustine Sylvain, born on 13 March 1786? He had no source of income other than "whatever his pen can produce," according to the testimony of Clavière. ${ }^{9}$

Actually, I think he did have another source: the Paris police, who probably paid him 150 livres a month, as was later claimed by Marat and others who knew him well. ${ }^{10}$ Far from being "paltry," as de Luna maintains, that sum would have been enough to keep the family together, though not much above the poverty line. It was at about this time that Filippo Mazzei visited the Brissots and was appalled to find them crammed into two rooms and dressed in "rags." 11 Jérôme Pétion, a close friend of Brissot's from their childhood days in Chartres, described him as trapped in poverty:

It was impossible to be simpler in dress, to keep a more frugal table, and in short to spend less money. . . . Brissot often did not have six francs in his pocket; he constantly had to borrow small sums from his friends. ${ }^{12}$

Poverty, back-breaking, bone-crushing, soul-destroying poverty, is the crucial fact in Brissot's career after 1784. Someone who has never felt the bite of poverty may find it impossible to believe that a man in Brissot's position would spy for the police. Someone who has may see things differently. I am arguing for a sympathetic approach to Brissot's career, not for sentimentalism. To make sense of his situation, one needs to know something about the hard realities of life in Grub Street, about the compromises writers had to make and the self-deceptions that they used to cover up those compromises.

But what was Grub Street, and can Brissot be considered one of its inhabitants? I would like to suspend the first question while taking up the second. Without denying Brissot's commitment to the principles of

${ }^{9}$ For details, see the full version of the letters exchanged by Clavière, the STN, and Brissot in "The Grub-Street Style of Revolution," 303-9. The version quoted in English in Darnton, The Literary Underground of the Old Regime (Cambridge, Mass., 1982), 44-48, is slightly abridged.

10 Marat, who was an intimate friend of Brissot's before the Revolution, later described his situation as follows: "There he was once again, out on the pavement, without a penny, and to top off his misery burdened with a wife and child. It is now notorious that having come to the end of his rope, he decided to offer his services to the lieutenant of police Lenoir, who made a royal observer of him for wages of 50 écus [ 150 livres] a month." J.-P. Marat, "Traits destinés au portrait du jésuite Brissot," in L'Ami du peuple, 4 June 1792, reprinted in Annales revolutionnaires 5 (1912): 689.

${ }^{11}$ Filippo Mazzei, Memoirs, trans. H. R. Narrari (New York, 1942), 229.

12 See Pétion's biographical sketch, printed in Claude Perroud, ed., Mémoires de J.-P. Brissot (1754-1793), publiés avec étude critique et notes (Paris, 1911) 2:365. 
the Enlightenment, I think he can best be described as a hack. Hard words, but he had a hard lot. A bankrupt, would-be philosophe could not feed a family by publishing treatises on truth in the Paris of 1785 . Brissot tried to make ends meet by writing pamphlets to manipulate the stock market for the benefit of his friend and patron, Etienne Clavière.

It would take a book to tell the full story of Brissot's financial pamphleteering, but I have summarized the main aspects of it in a recent article; ${ }^{13}$ so I will be brief here. Clavière's papers in the Bibliothèque nationale show that he paid Brissot thousands of livres between 1785 and 1789. Most of the money probably helped Brissot meet his debts; some, paid out in sums of 200 or 300 livres every month or so, covered a portion of his living expenses; and some went for speculations on futures in shares of stock companies, which Clavière bought in Brissot's name, betting on a bear market. Meanwhile, Clavière put much larger sums, hundreds of thousands of livres, on his own bets, which took the form of marchés à terme. He would contract to sell shares, which he did not own, at a high price on a future date. Expecting the value of the shares to drop, he would buy them at a low price just before that date and pocket the difference. The trick was to make sure that the value of the shares really did fall. Clavière did so by commissioning pamphlets.

He commissioned a dozen of them, from De la caisse d'escompte (1785) to Dénonciation de l'agiotage (1787), and De la foi publique envers les créanciers de l'Etat (1788). Many carried Mirabeau's name on their title page, but most were written, in part or entirely, by Brissot. All of them attacked the assets of companies on which Clavière was speculating. In vehemently moralistic and even Rousseauistic language, they denounced conspiracies to inflate the value of the companies' stock; and so, by provoking a run on the stock, they fulfilled the strategy of the bear speculators. The struggle between the bears and bulls (baissiers and haussiers) remained purely financial until 1785, when it became concentrated on shares in the Compagnie des eaux. Etienne de Calonne, the Controller General, had a personal interest of 230,000 livres' worth of shares in the company, and he had secretly subsidized it with 1,200,000 livres from the royal treasury. More important, he was trying to avert a collapse of the stock market and of the state's finances in general, which teetered dangerously close to bankruptcy in 1786. Clavière had invested too much in rentes viagères to favor bankruptcy-

13 Robert Darnton, "Ideology on the Bourse," in L'Image de la Révolution française: Communications presentées lors du Congrès Mondial pour le Bicentenaire de la Révolution, ed. Michel Vovelle (Paris and Oxford, 1989), 1:124-39. 
hence Brissot's pamphlet Point de banqueroute (1787)-but Clavière had 360,000 livres riding on a marché à terme that became due in March 1787, just when the Assembly of Notables began to meet to consider Calonne's reform program. The political, financial, and ideological issues all came together in the crisis that produced the fall of Calonne and the outbreak of the "pre-revolution." 14 They also came together in the most important attack on Calonne, perhaps the most important pamphlet of the eighteenth century before Sieyès's Qu'est-ce que le Tiers Etat?: the Dénonciation de l'agiotage, which was published under Mirabeau's name and written by Brissot and others in Clavière's stable of authors.

Put crudely, Clavière saved Brissot from ruin after 1784, and Brissot repaid him in pamphlets that promoted Clavière's interests in the struggle on the Bourse and ultimately helped precipitate the collapse of the Old Regime. But that interpretation leaves out a great deal. Brissot and Clavière seem to have been bound by genuine affection, not merely by a patron-client relationship. They probably believed in their propaganda, for self-interest does not preclude ideological commitment. It is even conceivable, though unlikely, that Brissot received so much money from Clavière that he did not need 150 livres a month from the police or that he ceased to work for the police when he took up writing for Clavière. (The first reference in Clavière's accounts to payments to Brissot occurs in December 1785, and Clavière did not give Brissot an account number and begin speculating for him until November 1786.) But a close reading of Brissot's pamphlets along with the entries in Clavière's account book does not bear out the casual remarks on Clavière's financial activities in Brissot's memoirs. A great deal of Brissot's writing from 1785 to 1788 was intended to manipulate the stock market. It was hack work by a hack writer, and the version of it in his memoirs was distorted, to say the least.

I could list many other distortions, notably in Brissot's account of his trip to the United States in 1788, which was intended primarily to promote speculations by Clavière and others on the American debt and not, as Brissot indicated, to study ways to promote a revolution in France. But a full comparison of what Brissot did as opposed to what he said he did would soon grow into a biography. Having got this far, it seems appropriate to step back from the details and to ask why one should become so exercised over the question of whether or not Brissot spied for the police.

${ }_{14}$ The term is Jean Egret's. See his excellent book, La Pre-révolution française (1787-1788) (Paris, 1962). 
First, I should say that "spying" need not have involved the denunciation of friends. It could have been a rather innocent form of reporting and perhaps of influencing public opinion through the production and distribution of pamphlets and manuscript gazettes. But no reinterpretation of the term can erase the opprobrium attached to it by Brissot's contemporaries. If literary life was so hard under the Old Regime that it broke idealistic young writers like Brissot and made them into secret agents of the police, we need to learn more about the facts of life for writers on the eve of the Revolution.

I have attempted to do so by putting Brissot's case aside in order to investigate his milieu, what I call Grub Street. Admittedly, the English term, which derives from an actual street in London, does not lend itself to a precise definition and may not fit French conditions. Still, the French frequently referred to hack writers-" "pauvres diables" and "la canaille de la littérature"-inhabiting a specific social space, the world of "la basse littérature," as Voltaire called it. ${ }^{15}$ This world was rich enough in humanity to provide a motif for many works of literature, including two masterpieces, Diderot's Neveu de Rameau and Rousseau's Confessions, which prepared the way for the supreme novel on the subject in the nineteenth century, Balzac's Illusions perdues. So in literary terms, the theme is as important in France as in England, where it inspired two other masterpieces, Pope's Dunciade and Johnson's Life of Mr. Richard Savage.

What was the social reality behind the literary theme? To put the question in that fashion may be to distort the answer, for it implies that literature expresses some pre-existing social condition and that one can understand a text by locating the social determinants behind it. I don't think that procedure is adequate even for an understanding of financial pamphleteering. Certainly Clavière paid Brissot, and Brissot wrote pamphlets designed to bring down the value of stock in accordance with Clavière's speculations à la baisse. But Clavière and Brissot perceived the Bourse through a haze of Rousseaustic moralizing. In 1789, when he drafted his own version of a declaration of the rights of man, Clavière included the following clause: "As the conservation of morals is absolutely necessary for maintaining the social contract, all financial operations connected with the public service must be considered in relation to morality." 16 That was the main theme of the pam-

15 For these and other terms, see my general essay on the subject, "The High Enlightenment and the Low-Life of Literature," in The Literary Underground of the Old Regime, 1-40.

${ }^{16}$ Darnton, "Ideology on the Bourse," 1:135. 
phlets he commissioned from Brissot and Mirabeau. They all meant to make money, but they also meant what they said.

I do not believe it is possible to exhaust the meaning of a text, even a financial pamphlet, by pointing to some vested interest lurking behind it. The interest may be there, but by exposing it, one has not necessarily produced an adequate interpretation of the text. The impulse to expose operates as a way of reducing literature to something taken as its socioeconomic "background." Instead of hunting for hidden background, I would favor an attempt to explore the social dimension of meaning - that is, to see how the fashioning of texts and the organization of social life belonged to the same process of making sense of things. In writing the Confessions, Rousseau made sense of his own experience in Grub Street; and in reading the Confessions-for the sixth time when he came to write his own memoirs-Brissot made sense of his life.

It does not follow that life is a text. Grub Street really existed, and it left its mark on hundreds of lives. How many, precisely? It is difficult to tote up sums while looking back over two centuries. But the sources are not as inadequate as one might think. I have studied five hundred police reports on authors in Paris around 1750. They refer to a large number of "pauvres diables," who slept under bridges and lived from the crumbs of the tables of the rich, like Rameau's nephew. In order to form some idea of the size of that milieu and of its importance within the Republic of Letters in general, I took some statistical soundings in La France littéraire, a kind of Who's Who of letters published throughout the second half of the eighteenth century. The results are only approximate, but they show that the literary population doubled from 1750 to 1789 and that it contained a huge number of impoverished hacks like Brissot-about a thousand, I would estimate. ${ }^{17}$

A thousand hack writers in a society about to explode in a revolution. They provided many of the explosives, and after the collapse of the Old Regime they generally enlisted as pamphleteers, journalists, and bureaucrats in the Revolution, just as Brissot and Manuel did. But some dropped out along the way, and some rallied to the counterrevolution. There is no simple formula that leads from Grub Street to Jacobinism. I am not advancing a simple cause-and-effect argument in

${ }^{17}$ See Robert Darnton, "A Police Inspector Sorts His Files: The Anatomy of the Republic of Letters," in The Great Cat Massacre and Other Episodes in French Cultural History (New York, 1984), 145-89; and "The Facts of Literary Life in Eighteenth-Century France," in The French Revolution and the Creation of Modern Political Culture, vol. 1: The Political Culture of the Old Regime, ed. Keith M. Baker (Oxford, 1987): 261-91. 
this respect any more than I am arguing that literature derives directly from the organization of society. If I had to translate my research into theoretical propositions, I would describe literature in terms used by Pierre Bourdieu - as a "field" with a peculiar social organization and "symbolic goods" perpetually at stake in the struggle to establish dominant positions (the Voltairean as opposed to the Rousseauistic, for example).

But even that formulation smacks of reductionism. I don't think we have any theory that does justice to the complexities of literary life in eighteenth-century France. That is why I believe it is important to make a close study of cases like Brissot's. By pursuing leads in archives, one can carry the history of ideas beyond the boundaries set by printed texts. One can analyze the social conditions of authorship, the politics and economics of publishing, the diffusion and reception of ideas, the formation of public opinion, and many other phenomena that belong to what may be called the social history of ideas. The label doesn't matter, provided that it not be taken as a justification for ignoring the ideas themselves or for dismissing texts as products of a social system. How can one relate literary expression to social experience? That is what the argument is about, but it is an argument, a matter of finding and construing evidence, not an attempt to pass a moral verdict on a poor devil who died two centuries ago. 